\title{
Alternative Coordination Modes in Palladium(II)-Diimino-Bispyridine Complexes with an Axially Chiral Biphenyl Backbone
}

\author{
Mika Kettunen, ${ }^{[a]}$ Christoph Vedder, ${ }^{[b]}$ Hans-Herbert Brintzinger, ${ }^{[b]}$ Ilpo Mutikainen, ${ }^{[a]}$ \\ Markku Leskelä, ${ }^{[\mathrm{a}]}$ and Timo Repo*[a]
}

\author{
Keywords: Chiral biaryl ligands / Palladium imino complexes / Binuclear complexes
}

The chiral biphenyl-bridged diimino-bispyridine ligands $N, N^{\prime}-\left(6,6^{\prime}\right.$-dimethylbiphenyl-2,2 -diyl)bis(2-pyridylmethyl)diimine(1)and $N_{,} N^{\prime}-\left(6,6^{\prime}\right.$-dimethylbiphenyl-2,2' -diyl)bis[(6methyl-2-pyridyl)methyl]diimine (2) react with $\mathrm{Pd}(\mathrm{COD}) \mathrm{Cl}_{2}$ to give, depending on the reaction conditions, either monoor binuclear $\mathrm{PdCl}_{2}$ complexes. In the binuclear complex 1 $\left(\mathrm{PdCl}_{2}\right)_{2}$, the Pd nuclei are held at a distance of $3.37 \AA$ by the ligand backbone. $N_{,} N^{\prime}-\left(6,6^{\prime}\right.$-dimethylbiphenyl-2,2'-diyl $)$ bis[(5-methyl-2-furyl)methyl]diimine (3), with furyl instead of pyridyl rings, gives mononuclear, $C_{2}$-symmetric complexes only. Reactions of $\left[\mathrm{Pd}\left(\mathrm{NCCH}_{3}\right)_{4}\right]^{2+}\left(\mathrm{BF}_{4}\right)_{2}$ with ligand 1 or 3 give the $\mathrm{C}_{2}$-symmetric cations $[1-\mathrm{Pd}]^{2+}$ or $\left[3-\mathrm{Pd}\left(\mathrm{NCCH}_{3}\right)_{2}\right]^{2+}$,

\section{Introduction}

Considerable attention has lately been focused on binuclear organometallic compounds, based on expectations that their reactivity in synthesis and catalysis may differ significantly from that of analogous mononuclear species. ${ }^{[1]}$ Interactions between closely adjacent metal centers might cause increased reaction rates or transformations not occurring with monometallic species, as was recently shown for copolymerization of styrene and ethene by binuclear titanocene complexes. ${ }^{[2]}$ The distance between two metal centers and their orientation to each other can be important for catalytic performance, as had been noted for binuclear rhodium hydroformylation catalysts ${ }^{[3]}$ and for palladium complexes that catalyze hydration reactions. ${ }^{[4]}$ Additional oxidation states might also be accessible in binuclear complexes as a result of stabilizing metal-metal interactions. ${ }^{[5]}$

Late transition metal complexes with nitrogen-based ligands have found a wide range of applications in homogeneous catalysis including polymerization of olefins or acrylates as well as hydrogenation reactions. ${ }^{[6]}$ Pyridylimine-Pd ${ }^{\mathrm{II}}$ chelates as dendrimeric complexes and binuclear $\mathrm{Pd}^{\mathrm{II}}$ complexes with long aliphatic spacers have recently been de-

[a] Laboratory of Inorganic Chemistry, University of Helsinki, 00014 Helsinki, Finland Fax: +358-9-1915-0198

E-mail: timo.repo@helsinki.fi [b] Fachbereich Chemie, Universität Konstanz, respectively, as their $\mathrm{BF}_{4}^{-}$salts. Solid-state structures of the chloride complexes 1- $\mathrm{PdCl}_{2}, 1-\left(\mathrm{PdCl}_{2}\right)_{2}$ and $3-\mathrm{PdCl}_{2}$, and of the complex cations $[1-\mathrm{Pd}]^{2+}$ and $\left[3-\mathrm{Pd}\left(\mathrm{NCCCH}_{3}\right)_{2}\right]^{2+}$ with tetradentate and bidentate ligand coordination, respectively, all show square-planar coordination, with some distortion toward tedrahedral geometry due to the twisted biaryl-backbone. Preliminary observations on norbornene polymerization with the catalysts $1-\mathrm{PdCl}_{2} / \mathrm{MAO}, 2-\mathrm{PdCl}_{2} / \mathrm{MAO}$ and [ $(3-$ $\left.\mathrm{Pd}\left(\mathrm{NCCH}_{3}\right)_{2}\right]^{2+}$ suggest that a certain degree of stereoregularity of the polymers is induced by these chiral catalysts.

scribed as effective catalyst precursors for Heck coupling[7] and for ethene polymerization, ${ }^{[8]}$ respectively, as well as with shorter chiral spacers to produce optically active polyketones. ${ }^{[9]}$ Palladium complexes with chiral bidentate bis(oxazoline) ligands have been shown to be efficient in asymmetric allylic alkylation, ${ }^{[10]}$ while biaryl Schiff base $\mathrm{Cu}$ complexes catalyze the aziridination of alkenes. ${ }^{[11]}$

With a structurally rigid 6,6'-disubstituted biaryl ligand backbone, the configuration of the ligand is fixed and its axial chirality can efficiently be transmitted to the stereotopicity of the active site. ${ }^{[12]}$ Biphenyl-bridged ligands form, in general, mononuclear complexes, ${ }^{[13]}$ but binuclear complexes, e. g. with $\mathrm{Cu}^{\mathrm{II}}$, have also been reported. ${ }^{[14]}$ Tetradentate $\mathrm{N}_{4}, \mathrm{~N}_{2} \mathrm{O}_{2}$ and $\mathrm{N}_{2} \mathrm{P}_{2}$ ligands are known to form both mono- and binuclear $\mathrm{Pd}^{\mathrm{II}}$ complexes, ${ }^{[15,16,17]}$ but only few of these have chiral biaryl backbones. ${ }^{[16 \mathrm{a}, 17 \mathrm{c}]}$

Since cationic $\mathrm{Pd}^{\mathrm{II}}$ complexes bearing diimine ligands with bulky substituents have been discovered to catalyze copolymerizations of $\alpha$-olefins with functional vinyl monomers, ${ }^{[18]}$ significant amounts of research have been aimed at tuning the electronic and steric properties of these ligands. Bulky aryls disfavor associative displacement and chain transfer reactions by steric protection of the electrophilic metal center; ligands with labile donor atoms like oxygen or sulfur in their side arms might likewise hinder $\beta-\mathrm{H}$ elimination by temporarily occupying a vacant site on the metal center. ${ }^{[19]}$ Interesting featuresmight thus be expected for $C_{2^{-}}$ symmetric $\mathrm{Pd}^{\mathrm{II}}$ diimine complexes with side-arm donors bridged by a chiral ligand backbone. 
In previous contributions, we have studied complexes of tetradentate 6,6'-dimethylbianiline-based ligands with metals such as $\mathrm{Zr}, \mathrm{Fe}, \mathrm{Co}$ or $\mathrm{Cr}$ in regard to their structures and catalytic activities. ${ }^{[20]}$ In this work, we extend these studies to mono- and bimetallic $\mathrm{Pd}^{\mathrm{II}}$ complexes bearing chiral diimino ligands with a biphenyl backbone.

\section{Results and Discussion}

Ligands 1, 2 and 3 were prepared, as described earlier, ${ }^{[20]}$ by imine condensation of $N, N^{\prime}-\left(6,6^{\prime}\right.$-dimethylbiphenyl-2,2' diyl)diamine with the required aldehydes. Reaction of $N, N^{\prime}-$ (6,6'-dimethylbiphenyl-2,2' -diyl) bis(2-pyridylmethyl)di-imine (1) with one equivalent of $\mathrm{Pd}(\mathrm{COD}) \mathrm{Cl}_{2}$ at $0{ }^{\circ} \mathrm{C}$ gave 1$\mathrm{PdCl}_{2}$, which precipitated from the reaction mixture in almost quantitative yield [Equation (1)]. When the reaction was repeated in an NMR tube, starting at $0^{\circ} \mathrm{C}$ and continuing at room temperature, the rate of the reaction was found to be quite fast; $95 \%$ of the $\mathrm{Pd}(\mathrm{COD}) \mathrm{Cl}_{2}$ was consumed after 30 minutes. Ligand 2 likewise reacted readily with $\mathrm{Pd}(\mathrm{COD}) \mathrm{Cl}_{2}$ under similar reaction conditions, but 2- $\mathrm{PdCl}_{2}$ was isolated with lower yield due to its higher solubility.
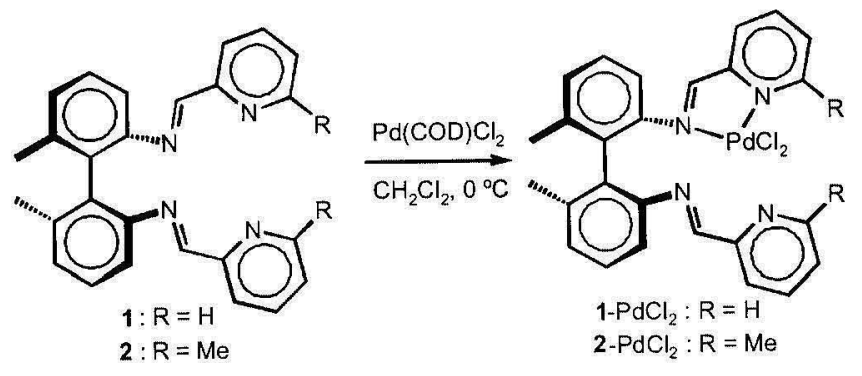

(1)

A single-crystal $\mathrm{X}$-ray structure analysis of $1-\mathrm{PdCl}_{2}$ confirms an approximately square-planar coordination of the $\mathrm{Pd}^{\mathrm{II}}$ cis-dichloro unit to one of the pyridylimine moieties of ligand 1 (Figure 1), which thus forms a five-membered pyridylimine chelate, with $\mathrm{Pd}-\mathrm{N}$ and $\mathrm{Pd}-\mathrm{Cl}$ distances (Table 1) close to values reported for similar complexes. ${ }^{[15-17]}$ In the solid state, the non-coordinated pyridylimine moiety lies on the backside of the biphenyl bridge, pointing away from the $\mathrm{PdCl}_{2}$ unit.

The ${ }^{1} \mathrm{H}$ NMR spectrum of 1-PdCl 2 in $\left[\mathrm{D}_{6}\right]$ DMSO solution reveals, instead of two singlets expected for the nonequivalent methyl groups in 6- and 6'-positions of the biaryl backbone, three sharp $\mathrm{CH}_{3}$ signals at $\delta=1.82,2.02$ and $2.23 \mathrm{ppm}$ with an integral ratio of 1:2:1. ${ }^{[21]}$ The occurrence of these three $\mathrm{CH}_{3}$ signals, as well as non-integer ratios for the aromatic proton signal integrals (see Experimental section), indicate the presence of two isomers in $\left[\mathrm{D}_{6}\right] \mathrm{DMSO}$ solution of 1-PdCl 2 , each with one Pd-coordinated and one non-coordinated ligand moiety. Related phenomena in connection with possible isomers of $1-\left(\mathrm{PdCl}_{2}\right)_{2}$ will be discussed below

For 2- $\mathrm{PdCl}_{2}$ in $\left[\mathrm{D}_{6}\right] \mathrm{DMSO}$ solution, however, only two singlets are observed, in agreement with the presence of a

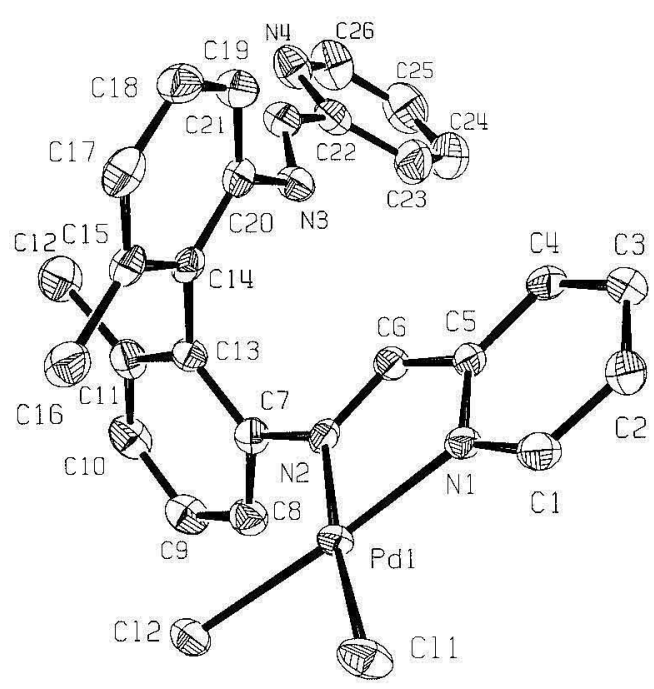

Figure 1. Crystal structure of 1- $\mathrm{PdCl}_{2}$ (ORTEP plot, thermal ellipsoids drawn at $50 \%$ probability, $\mathrm{H}$ atoms and $\mathrm{CH}_{2} \mathrm{Cl}_{2}$ solvent molecules omitted for clarity).

Table 1. Selected bond lengths $(\AA)$ and angles $\left[{ }^{\circ}\right]$ for $1-\mathrm{PdCl}_{2}$ (c.f. Figure 1).

\begin{tabular}{llll}
\hline $\mathrm{Pd}(1)-\mathrm{N}(1)$ & $2.022(3)$ & $\mathrm{N}(1)-\mathrm{Pd}(1)-\mathrm{N}(2)$ & $80.38(12$ \\
$\operatorname{Pd}(1)-\mathrm{N}(2)$ & $2.037(3)$ & $\mathrm{N}(1)-\mathrm{Pd}(1)-\mathrm{Cl}(2)$ & $175.56(9)$ \\
$\operatorname{Pd}(1)-\mathrm{Cl}(2)$ & $2.2893(11)$ & $\mathrm{N}(2)-\mathrm{Pd}(1)-\mathrm{Cl}(2)$ & $95.26(9)$ \\
$\operatorname{Pd}(1)-\mathrm{Cl}(1)$ & $2.2916(11)$ & $\mathrm{N}(1)-\mathrm{Pd}(1)-\mathrm{Cl}(1)$ & $93.28(9)$ \\
& & $\mathrm{N}(2)-\mathrm{Pd}(1)-\mathrm{Cl}(1)$ & $173.61(9)$ \\
& & $\mathrm{Cl}(2)-\mathrm{Pd}(1)-\mathrm{Cl}(1)$ & $91.06(4)$ \\
\hline
\end{tabular}

Pd-coordinated and an uncoordinated ligand moiety, for the methyl groups at the biphenyl bridge (1.96 and $2.05 \mathrm{ppm}$ ), for the methyl groups in 6-position of each pyridyl ring (2.47 and $2.80 \mathrm{ppm}$ ) and for the imine protons (8.21 and $8.69 \mathrm{ppm})$.

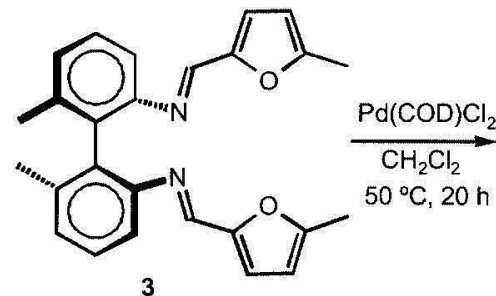

3

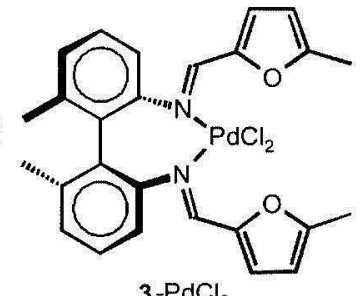

3- $\mathrm{PdCl}_{2}$
With ligand 3, where the side-arm pyridyl groups are replaced by furyl rings, a significantly longer reaction time $(20 \mathrm{~h})$ was required for complex formation with $\mathrm{Pd}(\mathrm{COD})$ $\mathrm{Cl}_{2}$ [Equation (2)]. As shown by the crystal structure of 3$\mathrm{PdCl}_{2}$ (Figure 2, Table 2), ligand 3 is bound in a bidentate manner again. Here, however, the two imino nitrogens form a seven-membered chelate with the cis-dichloro Pd unit to give an approximately square-planar and $C_{2}$-symmetric geometry. Due to the dihedral angle of $67^{\circ}$ between the phenyl rings of the biphenyl bridge, the ligand plane at the Pd center is somewhat distorted, with an angle of $5.9(2)^{\circ}$ spanned by the planes Cl1-Pd-N1 and Cl2-Pd-N2. The furyl oxy- 
gen atoms are located at non-bonding distances of 5.0 and $5.1 \AA$ from the Pd center, from which the side arms are pointing away. ${ }^{[22]}$ The preference of the $\mathrm{Pd}$ center for $\mathrm{N}$ over $\mathrm{O}$ ligand atoms obviously overrides its preference for fivemembered over seven-membered chelate rings to such an extent that a $C_{2}$-symmetric geometry becomes favored for $3-\mathrm{PdCl}_{2}$ over the $C_{1}$-symmetric structures of $1-\mathrm{PdCl}_{2}$ and 2- $\mathrm{PdCl}_{2}$.

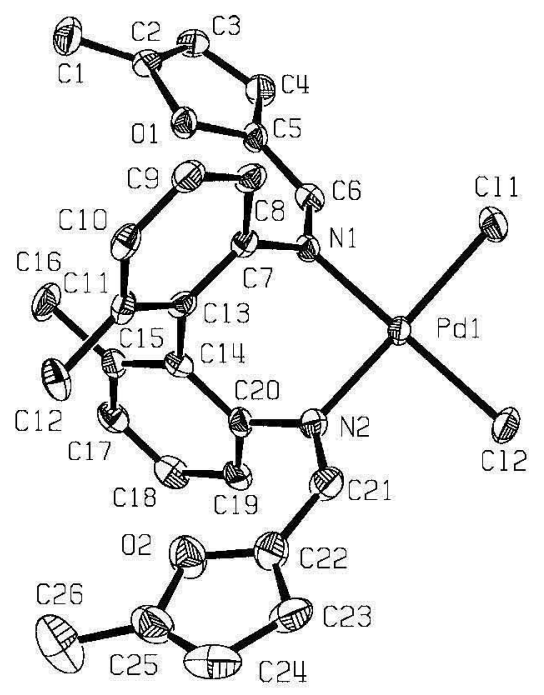

Figure 2. Crystal structure of 3-PdCl $\mathrm{PdORTP}_{2}$ (Olot, thermal ellipsoids drawn at $50 \%$ probability, $\mathrm{H}$ atoms and $\mathrm{CH}_{2} \mathrm{Cl}_{2}$ solvent molecule omitted for clarity).

Table 2. Selected bond lengths $(\AA)$ and angles $\left[{ }^{\circ}\right]$ for 3$\mathrm{PdCl}_{2} \cdot \mathrm{CH}_{2} \mathrm{Cl}_{2}$ (c.f. Figure 2).

\begin{tabular}{llll}
\hline $\mathrm{Pd}(1)-\mathrm{N}(1)$ & $2.029(3)$ & $\mathrm{N}(1)-\mathrm{Pd}(1)-\mathrm{N}(2)$ & $90.26(11)$ \\
$\mathrm{Pd}(1)-\mathrm{N}(2)$ & $2.057(3)$ & $\mathrm{N}(1)-\mathrm{Pd}(1)-\mathrm{Cl}(1)$ & $89.26(8)$ \\
$\mathrm{Pd}(1)-\mathrm{Cl}(1)$ & $2.2944(9)$ & $\mathrm{N}(2)-\mathrm{Pd}(1)-\mathrm{Cl}(1)$ & $174.45(9)$ \\
$\mathrm{Pd}(1)-\mathrm{Cl}(2)$ & $2.2973(9)$ & $\mathrm{N}(1)-\mathrm{Pd}(1)-\mathrm{Cl}(2)$ & $177.96(9)$ \\
& & $\mathrm{N}(2)-\mathrm{Pd}(1)-\mathrm{Cl}(2)$ & $90.17(8)$ \\
& & $\mathrm{Cl}(1)-\mathrm{Pd}(1)-\mathrm{Cl}(2)$ & $90.51(4)$ \\
\hline
\end{tabular}

$\mathrm{CDCl}_{3}$ solutions of $3-\mathrm{PdCl}_{2}$ give ${ }^{1} \mathrm{H}$ NMR spectra in agreement with an apparent $C_{2}$ symmetry, with a singlet at $\delta=1.88 \mathrm{ppm}$ due to the two methyl groups in the biphenyl backbone, another singlet at $\delta=2.18 \mathrm{ppm}$ due to the methyl groups at the furyl rings, and a singlet at $\delta=8.32 \mathrm{ppm}$ assigned to the imine protons. These signals are accompanied, however, by a set of smaller signals located slightly up-field, at $\delta=1.82,2.12$ and $8.29 \mathrm{ppm}$, which integrate to ratios of ca. 1:10 relative to the respective main peaks. The observation of this additional signal set in solutions of $3-\mathrm{PdCl}_{2}$ would indicate that some minor isomer is present, in addition to the structure represented in Figure 2. From our data it is not clear, which alternative geometry prevails in this isomer, whether (and how) e. g. furyl oxygen atoms might be coordinated to the $\mathrm{Pd}^{\mathrm{II}}$ center. ${ }^{[19]}$
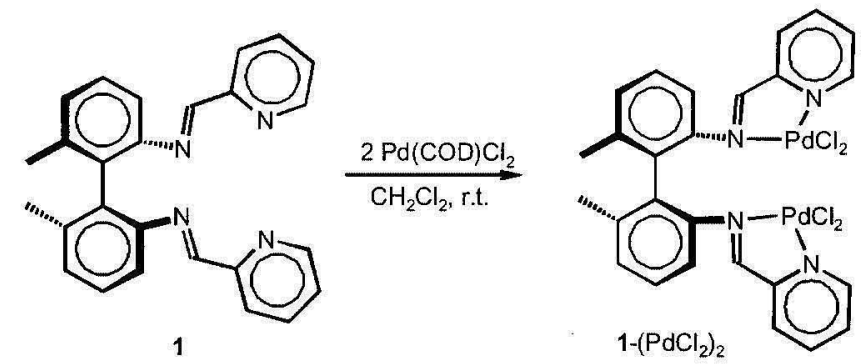

(3)

In $1-\mathrm{PdCl}_{2}$ one halve of ligand 1 remains available for further coordination and provides a possibility for the preparation of bimetallic complexes. The dipalladium complex 1- $\left(\mathrm{PdCl}_{2}\right)_{2}$ was indeed isolated in $97 \%$ yield when ligand 1 was treated with two equivalents of $\mathrm{Pd}(\mathrm{COD}) \mathrm{Cl}_{2}$ at room temperature [Equation (3)]. ${ }^{[23]}$ In the solid-state structure of binuclear 1-( $\left(\mathrm{PdCl}_{2}\right)_{2}$, one $\mathrm{PdCl}_{2}$ unit is coordinated, as expected, to each of the biphenyl-bridged pyridylimine moieties (Figure 3, Table 3). The two square-planar $\mathrm{N}_{2} \mathrm{PdCl}_{2}$ units are almost parallel to each other, stacking under an angle of $7.40(2)^{\circ}$. Viewed along the $\mathrm{Pd}-\mathrm{Pd}$ axis, the two $\mathrm{PdCl}_{2}$ units are rotated by an angle of $104.9^{\circ}$ relative to each other. The $\operatorname{Pd}(1)-\operatorname{Pd}(2)$ distance of $3.37 \AA$ is in the range of quite a number of binuclear $\mathrm{Pd}^{\mathrm{II}}$ complexes with relatively short (2-4 atom) bridging ligands. ${ }^{[24]}$ Apparently a similarly favorable situation for a close $\mathrm{Pd}^{\mathrm{II}} . . \mathrm{Pd}^{\mathrm{II}}$ contact is created by the preference of the biaryl bridge for a twist angle of ca. $70^{\circ}$. In addition, some attractive interaction between $\mathrm{Pd}-\mathrm{Cl}$ dipoles might contribute to keep the Pd centers at a distance close to the sum of their van-der-Waals radii.

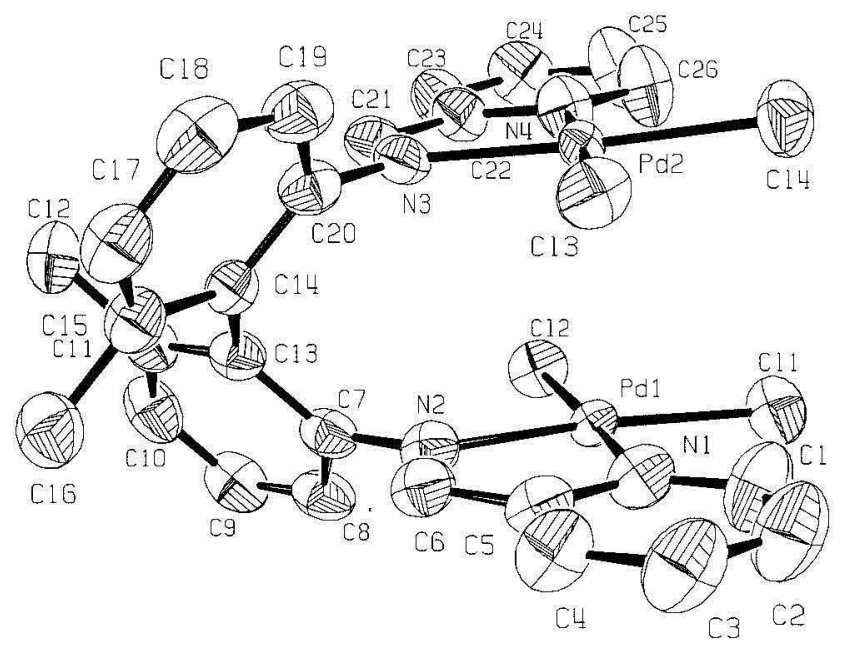

Figure 3. Crystal structure of 1-( $\left.\mathrm{PdCl}_{2}\right)_{2}(\mathrm{ORTEP}$ plot, thermal ellipsoids drawn at $50 \%$ probability, $\mathrm{H}$ atoms and $\mathrm{CH}_{2} \mathrm{Cl}_{2}$ solvent molecules omitted for clarity).

In the ${ }^{1} \mathrm{H}$ NMR spectra of $1-\left(\mathrm{PdCl}_{2}\right)_{2}$ in $\left[\mathrm{D}_{6}\right] \mathrm{DMSO}$ solution, the methyl groups at the biphenyl bridge give rise to a sharp signal at $\delta=2.02 \mathrm{ppm}$ and a broader one at $\delta=$ $2.12 \mathrm{ppm}$, each corresponding to 3 protons; the 6-posi- 
Table 3. Selected bond lengths $(\AA)$ and angles $\left[{ }^{\circ}\right]$ for $1-\left(\mathrm{PdCl}_{2}\right)_{2}$. $2 \mathrm{CH}_{2} \mathrm{Cl}_{2}$ (c.f. Figure 3).

\begin{tabular}{llll}
\hline $\operatorname{Pd}(1)-\mathrm{N}(1)$ & $2.034(6)$ & $\mathrm{N}(1)-\mathrm{Pd}(1)-\mathrm{N}(2)$ & $79.8(3)$ \\
$\operatorname{Pd}(1)-\mathrm{N}(2)$ & $2.048(6)$ & $\mathrm{N}(1)-\operatorname{Pd}(1)-\mathrm{Cl}(1)$ & $94.4(2)$ \\
$\operatorname{Pd}(1)-\mathrm{Cl}(1)$ & $2.292(2)$ & $\mathrm{Cl}(1)-\mathrm{Pd}(1)-\mathrm{Cl}(2)$ & $88.56(7)$ \\
$\operatorname{Pd}(1)-\mathrm{Cl}(2)$ & $2.2930(19)$ & $\mathrm{N}(2)-\mathrm{Pd}(1)-\mathrm{Cl}(1)$ & $173.42(19)$ \\
& & $\mathrm{N}(1)-\operatorname{Pd}(1) \mathrm{Cl}(2)$ & $176.94(19)$ \\
& & $\mathrm{N}(2)-\mathrm{Pd}(1)-\mathrm{Cl}(2)$ & $97.31(18)$ \\
& & $\mathrm{C}(1)-\mathrm{N}(1)-\mathrm{Pd}(1)$ & $127.1(6)$ \\
$\operatorname{Pd}(2)-\mathrm{N}(3)$ & $2.044(6)$ & $\mathrm{C}(5)-\mathrm{N}(1)-\mathrm{Pd}(1)$ & $113.7(5)$ \\
$\operatorname{Pd}(2)-\mathrm{N}(4)$ & $2.056(6)$ & $\mathrm{N}(3)-\mathrm{Pd}(2)-\mathrm{N}(4)$ & $80.3(2)$ \\
$\operatorname{Pd}(2)-\mathrm{Cl}(3)$ & $2.300(2)$ & $\mathrm{N}(3)-\mathrm{Pd}(2)-\mathrm{Cl}(3)$ & $173.60(18)$ \\
$\operatorname{Pd}(2)-\mathrm{Cl}(4)$ & $2.281(2)$ & $\mathrm{N}(4)-\mathrm{Pd}(2)-\mathrm{Cl}(4)$ & $97.19(18)$ \\
& & $\mathrm{Cl}(4)-\mathrm{Pd}(2)-\mathrm{Cl}(3)$ & $89.04(19)$ \\
\hline
\end{tabular}

tioned protons of the pyridyl rings likewise appear as two doublets at 8.83 and at $\delta=9.04 \mathrm{ppm}$ representing one proton each and the other aromatic and imine signals are also grouped in a manner incompatible with a $C_{2}$-symmetric complex. These observations can be explained either by the occurrence of two diastereomers, e.g. meso- and rac-like conformers of the two complex moieties, in a ratio of ca. $1: 1$ or by some nonequivalence of the two complex moieties in solution, caused e.g. by co-ordination of a solvent molecule to one of the Pd centers. Our data do not allow us to estimate the lifetimes of isomers of this kind.

The cis- $\mathrm{PdCl}_{2}$ unit considered so far obviously favors formation of a five-membered pyridyl-imine chelate over that of a seven-membered diimine chelate; complexes such as $1-\mathrm{PdCl}_{2}$ or $2-\mathrm{PdCl}_{2}$ are thus of $C_{1}$ symmetry. In order to synthesize complexes which fully exploit the axialsymmetry inherent in the biaryl backbone to generate $C_{2}$-symmetric complexes suitable for asymmetric catalysis, ${ }^{[25]}$ we have sought to induce tetradentate coordination of ligands $\mathbf{1}$ and 2 with formation of cationic complexes by use of the more electron-deficient $\mathrm{Pd}$ precursor $\left[\mathrm{Pd}\left(\mathrm{NCCH}_{3}\right)_{4}\right]^{2+}\left(\mathrm{BF}_{4}^{-}\right)_{2}$ [Equation (4)].

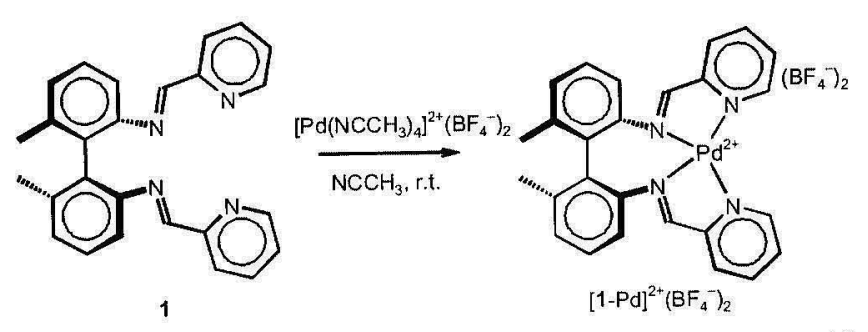

(4)

Reaction of ligand 1 with one equivalent of $[\mathrm{Pd}-$ $\left.\left(\mathrm{NCCH}_{3}\right)_{4}\right]^{2+}\left(\mathrm{BF}_{4}^{-}\right)_{2}$ in acetonitrile at room temperature gave the ion pair $[1-\mathrm{Pd}]^{2+}\left(\mathrm{BF}_{4}^{-}\right)_{2}$ in high yield. The expected tetradentate coordination of ligand 1 in $[1-\mathrm{Pd}]^{2+}$ $\left(\mathrm{BF}_{4}^{-}\right)_{2}$ was verified by single-crystal structure determination (Figure 4). The Pd center forms an approximately $C_{2}$-symmetric seven-membered chelate ring with the biphenyl-bridged imine nitrogens and one five-membered che- late ring with each of the pyridylimine moieties, with $\mathrm{Pd}-\mathrm{N}$ distances (Table 4) in the range reported for other Pd-imino complexes. ${ }^{[15-17]}$ Due to the dihedral angle of $71^{\circ}$ in the 2,2'-dimethyl-substituted biphenyl backbone, the squareplanar coordination at the $\mathrm{Pd}$ atom shows some tetrahedral distortion, so that the planes N1-Pd-N2 and N3-Pd-N4 span an angle of $12.9(5)^{\circ} .{ }^{[26]}$

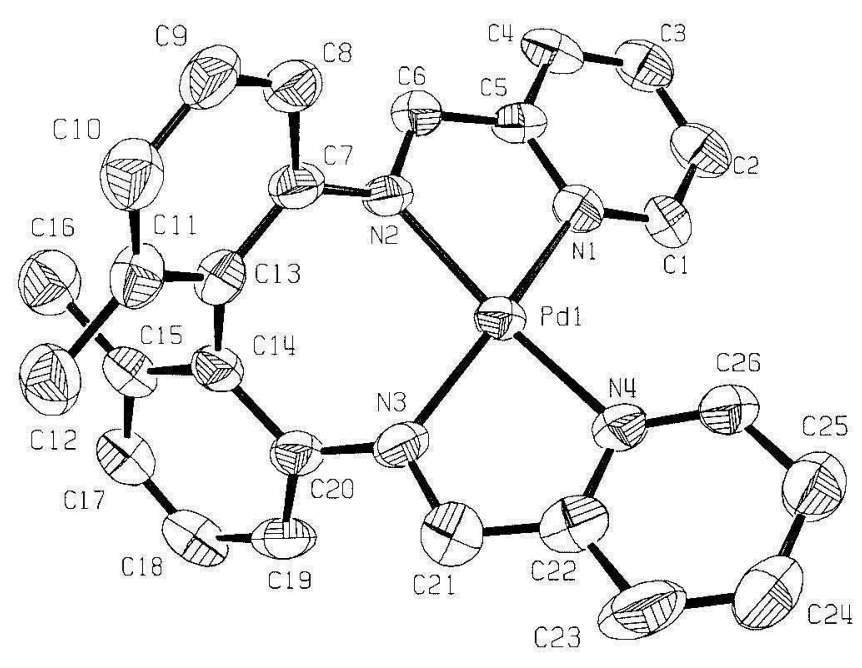

Figure 4. Crystal structure of $[1-\mathrm{Pd}]^{2+}\left(\mathrm{BF}_{4}{ }^{-}\right)_{2}$ (ORTEP plot, thermal ellipsoids drawn at $50 \%$ probability, $\mathrm{H}$ atoms, $0.5 \mathrm{H}_{2} \mathrm{O}$ and $\mathrm{BF}_{4}{ }^{-}$omitted for clarity).

Table 4. Selected bond lengths $(\AA)$ and angles $\left[^{\circ}\right]$ for $[1-P d]^{2+}$. $\left(\mathrm{BF}_{4}^{-}\right)_{2}$ (c.f. Figure 4).

\begin{tabular}{llll}
\hline $\operatorname{Pd}(1)-\mathrm{N}(3)$ & $2.012(7)$ & $\mathrm{N}(3)-\mathrm{Pd}(1)-\mathrm{N}(2)$ & $99.0(3)$ \\
$\operatorname{Pd}(1)-\mathrm{N}(2)$ & $2.017(6)$ & $\mathrm{N}(3)-\mathrm{Pd}(1)-\mathrm{N}(4)$ & $80.4(3)$ \\
$\operatorname{Pd}(1)-\mathrm{N}(4)$ & $2.021(7)$ & $\mathrm{N}(2)-\mathrm{Pd}(1)-\mathrm{N}(4)$ & $161.7(3)$ \\
$\operatorname{Pd}(1)-\mathrm{N}(1)$ & $2.044(7)$ & $\mathrm{N}(3)-\mathrm{Pd}(1)-\mathrm{N}(1)$ & $164.5(3)$ \\
& & $\mathrm{N}(2)-\mathrm{Pd}(1)-\mathrm{N}(1)$ & $79.7(3)$ \\
& & $\mathrm{N}(4)-\mathrm{Pd}(1)-\mathrm{N}(1)$ & $105.6(3)$ \\
\hline
\end{tabular}

${ }^{1} \mathrm{H}$ NMR spectra in $\mathrm{CD}_{3} \mathrm{CN}$ solution indicate, again, some deviations of the cation $[1-\mathrm{Pd}]^{2+}$ from the approximate $C_{2}$ symmetry found in the solid state. The 6,6'-positioned methyl groups of the ligand backbone give rise to a multiplet with two maxima at $\delta=1.72$ and $1.76 \mathrm{ppm}$, and the aromatic protons are likewise grouped in multiplets which do not appear to be compatible with an overall $C_{2}$ symmetry. Even though we do not have any direct evidence in this regard, we would assume that the equivalence of both halves of the complex molecule might be destroyed, as in the cases discussed above, by coordination of a solvent molecule.

In order to test whether a tetradentate coordination similar to that achieved for ligand $\mathbf{1}$ might also be accessible for the furyl-substituted ligand $\mathbf{3}{ }^{[27]}$ the latter was likewise reacted with $\left[\mathrm{Pd}\left(\mathrm{NCCH}_{3}\right)_{4}\right]^{2+}\left(\mathrm{BF}_{4}^{-}\right)_{2}$ in acetonitrile solution. The reaction proceeded fast and with high yield, but gave, instead of a product with tetracoordinate ligand $\mathbf{3}$, [3$\mathrm{Pd}]^{2+}\left(\mathrm{BF}_{4}^{-}\right)_{2}$, the bis(acetonitrile) adduct [3-Pd- $\left.\left(\mathrm{NCCH}_{3}\right)_{2}\right]$ ${ }^{2+}\left(\mathrm{BF}_{4}^{-}\right)_{2}$ [Equation (5)]. 


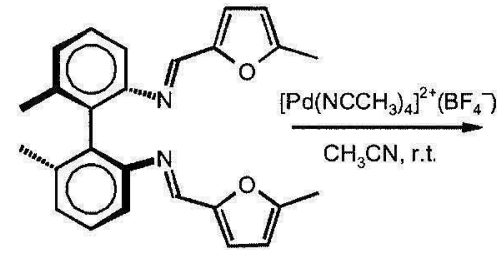

3

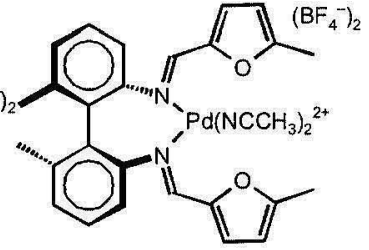

$\left[3-\mathrm{Pd}\left(\mathrm{NCCH}_{3}\right)_{2}\right]^{2+}\left(\mathrm{BF}_{4}\right)_{2}$
In the crystal structure of $\left[3-\mathrm{Pd}\left(\mathrm{NCCH}_{3}\right)_{2}\right]^{2+}\left(\mathrm{BF}_{4}^{-}\right)_{2}$ (Figure 5, Table 5), square-planar coordination at the cationic Pd center is found to involve two cis-positioned acetonitrile ligands and the two imino nitrogen atoms of ligand 3; as in $\mathbf{3}-\mathrm{PdCl}_{2}$, the ligand $\mathbf{3}$ forms again a seven-membered chelate ring with the $\mathrm{Pd}$ center. In distinction to $3-\mathrm{PdCl}_{2}$, however, where the furyl oxygen atoms point away from the $\mathrm{Pd}$ center, they are now turned towards the latter and lie rather close to it, in pseudo-axial positions at $\mathrm{Pd}-\mathrm{O}$ distances of 3.0(1) $\AA$. Some (presumably weak) coordination or dipolar attraction of the furyl oxygen atoms to the $\mathrm{Pd}^{\mathrm{II}}$ center thus appears to be stabilized by the cationic nature of the metal. ${ }^{[27,28]}$

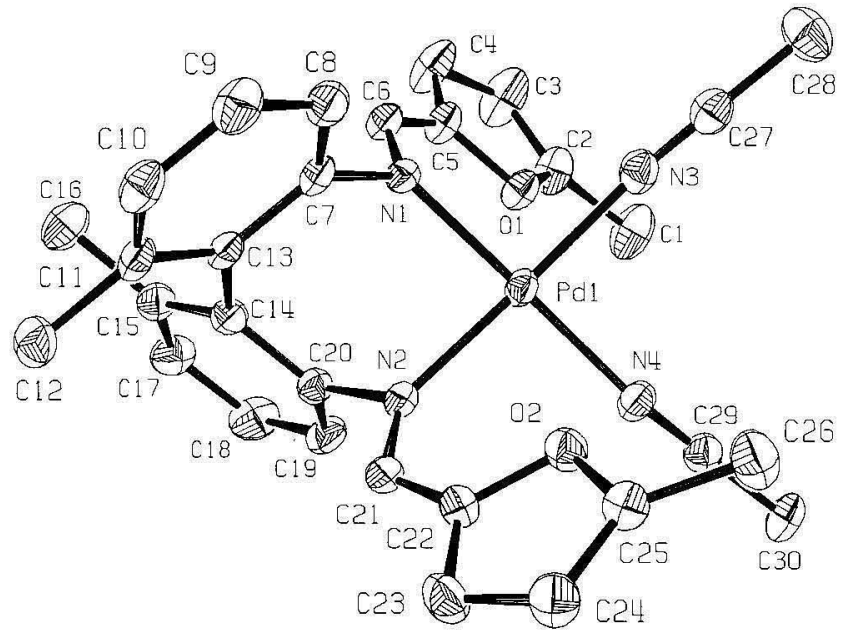

Figure 5. Crystal structure of $\left[3-\mathrm{Pd}\left(\mathrm{NCCH}_{3}\right)_{2}\right]^{2+}\left(\mathrm{BF}_{4}{ }^{-}\right)_{2}(\mathrm{ORTEP}$ plot, thermal ellipsoids drawn at $50 \%$ probability, $\mathrm{H}$ atoms, $\mathrm{CH}_{3} \mathrm{CN}$ solvent molecule and $\mathrm{BF}_{4}^{-}$omitted for clarity).

Table 5. Selected bond lengths $(\AA)$ and angles $\left[{ }^{\circ}\right]$ for $[3-P d-$ $\left.\left(\mathrm{NCCH}_{3}\right)_{2}\right]^{2+}\left(\mathrm{BF}_{4}^{-}\right)_{2}$ (c.f. Figure 5).

\begin{tabular}{llll}
\hline $\operatorname{Pd}(1)-\mathrm{N}(1)$ & $2.006(2)$ & $\mathrm{N}(1)-\mathrm{Pd}(1)-\mathrm{N}(4)$ & $171.03(8)$ \\
$\operatorname{Pd}(1)-\mathrm{N}(4)$ & $2.009(2)$ & $\mathrm{N}(1)-\mathrm{Pd}(1)-\mathrm{N}(2)$ & $86.35(9)$ \\
$\operatorname{Pd}(1)-\mathrm{N}(2)$ & $2.016(2)$ & $\mathrm{N}(4)-\operatorname{Pd}(1)-\mathrm{N}(2)$ & $93.37(9)$ \\
$\operatorname{Pd}(1)-\mathrm{N}(3)$ & $2.022(2)$ & $\mathrm{N}(1)-\operatorname{Pd}(1)-\mathrm{N}(3)$ & $91.97(9)$ \\
& & $\mathrm{N}(4)-\operatorname{Pd}(1)-\mathrm{N}(3)$ & $89.15(9)$ \\
& & $\mathrm{N}(2)-\mathrm{Pd}(1)-\mathrm{N}(3)$ & $174.21(8)$ \\
\hline
\end{tabular}

The ${ }^{1} \mathrm{H}$ NMR spectrum of $\left[3-\mathrm{Pd}\left(\mathrm{NCCH}_{3}\right)_{2}\right]^{2+}$ is entirely in agreement with the overall $C_{2}$ symmetry expected from its solid-state structure. Its $\mathrm{NCCH}_{3}$ ligands and its biphenyl and furyl methyl substituents give rise to only one singlet signal each, at $\delta=2.08,2.20$ and $2.63 \mathrm{ppm}$, respectively. Apparently, the binding of the furyl groups to the cationic $\mathrm{Pd}^{\mathrm{II}}$ center, however weak, protects the latter from interaction with a solvent donor, which might otherwise destroy the overall $C_{2}$ symmetry of the complex molecule in solution.

Since two nitrogen ligand atoms are sufficient for the formation of a cationic di-acetonitrile complex, ligand 1 was also treated with two equivalents of $\left[\mathrm{Pd}\left(\mathrm{NCCH}_{3}\right)_{4}\right]\left(\mathrm{BF}_{4}\right)_{2}$ to prepare the binuclear cationic complex 1-([Pd$\left.\left.\left(\mathrm{NCCH}_{3}\right)_{2}\right]^{2+}\right)_{2}\left(\mathrm{BF}_{4}^{-}\right)_{4}$ [Equation (6)]. The reaction yielded an oily product, the elemental analysis and ${ }^{1} \mathrm{H}$ NMR spectra of which indicated formation of the expected complex. As no crystals suitable for X-ray diffraction were obtained, it was not possible to study the effect of the increased charges on the mutual arrangement of the metal centers in this binuclear complex.

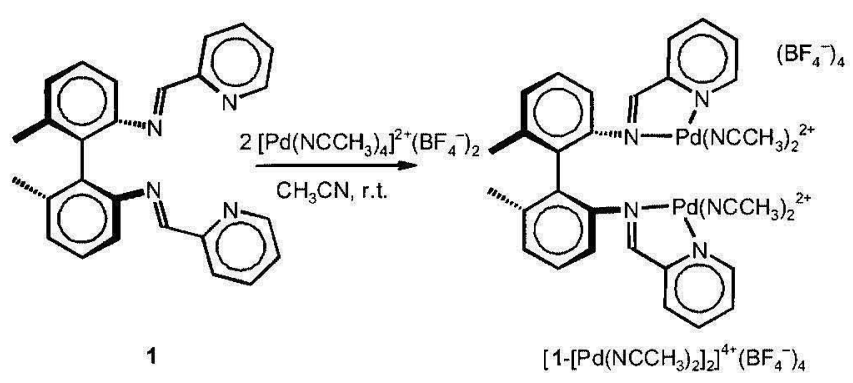

Preliminary data concerning catalytic activities of the new $\mathrm{Pd}^{\mathrm{II}}$ complexes described above were obtained with regard to polymerization of norbornene at room temperature. ${ }^{[29]}$ When activated by addition of methylaluminoxane (MAO), the dichloro complexes 1- $\mathrm{PdCl}_{2}, 2-\mathrm{PdCl}_{2}$ and 3$\mathrm{PdCl}_{2}$ gave polymers which were insoluble in organic solvents such as trichlorobenzene even at elevated temperatures. The cationic complex $\left[3-\mathrm{Pd}\left(\mathrm{NCCH}_{3}\right)_{2}\right]^{2+}\left(\mathrm{BF}_{4}^{-}\right)_{2}$ gave, without activation by $\mathrm{MAO},{ }^{[29]}$ polymers with good solubility, e.g. in toluene or chloroform, in moderate yield. For these polynorbornenes, a molar mass of $33800 \mathrm{~g} / \mathrm{mol}$ and a polydispersity index of 1.26 were determined. Complex [1$\mathrm{Pd}]^{2+}\left(\mathrm{BF}_{4}^{-}\right)_{2}$, in which the $\mathrm{Pd}$ center is bound to all four $\mathrm{N}$ atoms of the tetradentate ligand, was found to be inactive for polymerization of norbornene at room temperature.

Decomposition temperatures, determined by thermogravimetric analysis, of the polymers obtained with $\mathrm{MAO}$ activated 1- $\mathrm{PdCl}_{2}, 2-\mathrm{PdCl}_{2}$ and 3- $\mathrm{PdCl}_{2}$ as well as of those obtained with $\left[\left(3-\mathrm{Pd}\left(\mathrm{NCCH}_{3}\right)_{2}\right]^{2+}\left(\mathrm{BF}_{4}^{-}\right)_{2}\right.$, were found to be exceptionally high $\left(\mathrm{ca} .450^{\circ} \mathrm{C}\right.$ ), i.e. more than $100^{\circ} \mathrm{C}$ higher than that $\left(335^{\circ} \mathrm{C}\right)$ determined for the polymer obtained with $\left[\mathrm{Pd}\left(\mathrm{NCCH}_{3}\right)_{4}\right]\left(\mathrm{BF}_{4}\right)_{2}{ }^{[29]}$ This might suggest that a certain degree of stereoregularity is induced in the polymer by the chiral ligands of the catalysts 1-PdCl$/ \mathrm{MAO}, 2-\mathrm{PdCl}_{2} /$ $\mathrm{MAO}, 3-\mathrm{PdCl} \mathrm{Cl}_{2} / \mathrm{MAO}$ and $\left[\left(3-\mathrm{Pd}\left(\mathrm{NCCH}_{3}\right)_{2}\right]^{2+} \cdot{ }^{[30]}\right.$ 


\section{Conclusions}

Axially symmetric, biphenyl-bridged diimino ligands with additional pyridyl or furyl side arms are highly versatile with respect to $\mathrm{Pd}^{\mathrm{II}}$ complex formation. Depending on the Pd precursors and the reaction conditions used, mononuclear-bidentate complexes of $C_{1}$ or $C_{2}$ symmetry, as well as binuclear and mononuclear-tetradentale $\mathrm{Pd}^{\mathrm{II}}$ complexes can be obtained in a controlled manner and with high yields. Preliminary observations indicate distinctly different properties of cationic species derived from them as norbornene polymerization catalysts.

\section{Experimental Section}

All complex preparation and polymerization reactions were performed under argon atmosphere using standard Schlenk techniques. $N, N^{\prime}-\left(6,6^{\prime}\right.$-Dimethylbiphenyl-2,2'-diyl)diamine, ${ }^{[31]}$ the 1 igands $1-3^{[20]}$ and dichloro(1,5-cyclooctadiene)palladium(II) $\left[\mathrm{Pd}(\mathrm{COD}) \mathrm{Cl}_{2}\right]$, ${ }^{[32]}$ were prepared as reported earlier. Solvents were dried prior to use by refluxing over and distillation from sodium (hydrocarbons), magnesium (alcohols), $\mathrm{P}_{2} \mathrm{O}_{5}$ (acetonitrile) or calcium hydride (dichloromethane). Deuterated solvents were dried over $4-\AA$ molecular sieves. All other chemicals were purchased from commercial suppliers and used without further purification. Elemental analyses were performed with an EA 1110 CHNS-O CE instrument. NMR spectra were collected with a Varian Gemini 200 spectrometer. Polymer molar mass and molar mass distributions were measured by gel permeation chromatography (GPC) relative to polystyrene standards.

$N, N^{\prime}-\left(6,6^{\prime}\right.$-Dimethylbiphenyl-2,2'-diyl)bis(2-pyridylmethyl)-diimine$\mathrm{PdCl}_{2}\left(1-\mathrm{PdCl}_{2}\right)$ : A solution of ligand $1(0.59 \mathrm{~g}, 1.52 \mathrm{mmol})$ and $\mathrm{Pd}(\mathrm{COD}) \mathrm{Cl}_{2}(0.39 \mathrm{~g}, 1.38 \mathrm{mmol})$ in $\mathrm{CH}_{2} \mathrm{Cl}_{2}(25 \mathrm{~mL})$ was stirred at $0{ }^{\circ} \mathrm{C}$. The product started to precipitate as a light yellow powder after $1 \mathrm{~h}$. After stirring for another $20 \mathrm{~h}$ at room temperature, the product was filtered, washed with diethyl ether and dried in vacuo. Yield $658 \mathrm{mg}, 84 \% .{ }^{1} \mathrm{H}$ NMR $\left(200 \mathrm{MHz},\left[\mathrm{D}_{6}\right] \mathrm{DMSO}\right): \delta=1.82$, 2.02 and 2.23 ( 3 lines, $\left.6 \mathrm{H}, \mathrm{CH}_{3}\right), 7.02(\mathrm{~d}, J=8.0 \mathrm{~Hz}, 0.5 \mathrm{H}, \mathrm{Ar}-$ $H), 7.25-7.39(\mathrm{~m}, 3.5 \mathrm{H}, \mathrm{Ar}-H), 7.5(\mathrm{~m}, 2 \mathrm{H}, \mathrm{Ar}-H), 7.71-7.94$ $(\mathrm{m}, 3.5 \mathrm{H}, \mathrm{Ar}-H), 8.21-8.27(\mathrm{~m}, 2.5 \mathrm{H}, \mathrm{CH}), 8.5(\mathrm{~s}, 0.5 \mathrm{H}$, imine$\mathrm{CH}), 8.64-8.71(\mathrm{~m}, 1 \mathrm{H}, \mathrm{CH}), 8.83-8.97(\mathrm{~m}, 1.5 \mathrm{H}, \mathrm{CH})$, $8.88 \mathrm{ppm}(\mathrm{s}, 1 \mathrm{H}$, imine-CH); elemental analysis (\%) calcd. for $\mathrm{C}_{26} \mathrm{H}_{22} \mathrm{Cl}_{2} \mathrm{~N}_{4} \mathrm{Pd}$ (567.81): C 55.00, H 3.91, N 9.87; found: $\mathrm{C} 54.70$, $\mathrm{H} 3.71, \mathrm{~N} 10.25$.

$N, N^{\prime}$-(6,6'-Dimethylbiphenyl-2,2'-diyl)bis[(6-methyl-2-pyridyl)methyldiimine- $\mathrm{PdCl}_{2}\left(2-\mathrm{PdCl}_{2}\right)$ : This complex was prepared in the same manner as described above for complex 1- $\mathrm{PdCl}_{2}$. Yield $0.16 \mathrm{~g}, 50 \%$. ${ }^{1} \mathrm{H}$ NMR $\left(200 \mathrm{MHz},\left[\mathrm{D}_{6}\right] \mathrm{DMSO}\right): \delta=1.96\left(\mathrm{~s}, 3 \mathrm{H}\right.$, biaryl- $\left.\mathrm{CH}_{3}\right)$, 2.05 (s, $3 \mathrm{H}$, biaryl- $\mathrm{CH}_{3}$ on $\mathrm{Pd}$-coordinated side), 2.47 (s, $3 \mathrm{H}$, pyridine- $\left.\mathrm{CH}_{3}\right), 2.80\left(\mathrm{~s}, 3 \mathrm{H}\right.$, pyridine- $\mathrm{CH}_{3}$ on Pd-side), 6.96 (d, $J=$ $8 \mathrm{~Hz}, 1 \mathrm{H}$, pyridine- $\mathrm{C} H), 7.16(\mathrm{~d}, J=8 \mathrm{~Hz}, 1 \mathrm{H}$, pyridine- $\mathrm{C} H)$, $7.24-7.48$ ( $\mathrm{m}, 6 \mathrm{H}, 1$ pyridine- $\mathrm{CH}$ and 2 biaryl- $\mathrm{CH}$ on non-coordinated side, and $3 \mathrm{Ar}-\mathrm{CH}$ on Pd-coordinated side), 7.65-7.73 (m, $2 \mathrm{H}, 1$ pyridine- $\mathrm{CH}$ from Pd-free side and $1 \mathrm{Ar}-H$ from Pd-coordinated side), 7.97-8.11 (br., $2 \mathrm{H}, \mathrm{Ar}-H$ on Pd-side), 8.21 (s, $1 \mathrm{H}$, imine-CH), 8.69 ppm (br., $1 \mathrm{H}$, Pd-coordinated imine-CH); elemental analysis (\%) calcd. for $\mathrm{C}_{28} \mathrm{H}_{26} \mathrm{Cl}_{2} \mathrm{~N}_{4} \mathrm{Pd}$ (595.86): C 56.44, H 4.40, N 9.40; found: C 55.85, H 4.34, N 9.21.

$N, N^{\prime}$-(6,6'-Dimethylbiphenyl-2,2'-diyl)bis[(5-methyl-2-furyl)methyl]diimine-PdCl $\mathbf{P d}_{2} \quad\left(3-\mathrm{PdCl}_{2}\right)$ : Ligand $3(0.49 \mathrm{~g}, 1.25 \mathrm{mmol})$ and $\mathrm{Pd}(\mathrm{COD}) \mathrm{Cl}_{2}(0.36 \mathrm{~g}, 1.25 \mathrm{mmol})$ were refluxed in $\mathrm{CH}_{2} \mathrm{Cl}_{2}(20 \mathrm{~mL})$ for $20 \mathrm{~h}$. Diethyl ether $(20 \mathrm{~mL})$ was added to reaction mixture, which was then filtered and kept at $-20^{\circ} \mathrm{C}$. The product was collected as orange crystals by filtration after $24 \mathrm{~h}$. Yield $0.36 \mathrm{~g}, 50 \%$. ${ }^{1} \mathrm{H}$ NMR $\left(200 \mathrm{MHz}, \mathrm{CDCl}_{3}\right): \delta=1.88\left(\mathrm{~s}, 6 \mathrm{H}\right.$, furyl-C $\left.\mathrm{CH}_{3}\right), 2.18(\mathrm{~s}$, $6 \mathrm{H}$, biaryl-CH$), 6.01(\mathrm{~d}, J=3.6 \mathrm{~Hz}, 2 \mathrm{H}$, furyl-CH$), 6.16(\mathrm{~d}, J=$ $3.2 \mathrm{~Hz}, 2 \mathrm{H}$, furyl-CH), $7.09(\mathrm{~d}, J=7.8 \mathrm{~Hz}, 2 \mathrm{H}$, biaryl-CH), 7.22 (d, $J=7.0 \mathrm{~Hz}, 2 \mathrm{H}$, biaryl-CH), 7.29 (pt, $J=7.6 \mathrm{~Hz}, 2 \mathrm{H}$, biaryl$\mathrm{CH}$ ), $8.32 \mathrm{ppm}(\mathrm{s}, 2 \mathrm{H}$ imine-CH). Minor isomer: 1.82 (s, biaryl$\mathrm{CH}_{3}$ ), 2.12 (s, furyl- $\mathrm{CH}_{3}$ ), $8.29 \mathrm{ppm}$ (s, imine-CH). ${ }^{13} \mathrm{C}$ NMR $\left(50 \mathrm{MHz}, \mathrm{CDCl}_{3}\right): \delta=13.9,18.7,109.9,120.3,124.5,127.7129 .3$, $129.7,138.5,145.9,146.4,156.3,159.5$ ppm; elemental analysis (\%) calcd. for $\mathrm{C}_{26} \mathrm{H}_{24} \mathrm{Cl}_{2} \mathrm{~N}_{2} \mathrm{O}_{2} \mathrm{Pd} \cdot \mathrm{CH}_{2} \mathrm{Cl}_{2}$ (658.75): C 49.23, H 3.98, $\mathrm{N}$ 4.25; found: C 48.26, H 4.57, N 4.06 .

$N, N^{\prime}$ - (6, $6^{\prime}$-Dimethylbiphenyl-2,2' -diyl)bis(2-pyridylmethyl)diimine$\left(\mathrm{PdCl}_{2}\right)_{2}\left[1-\left(\mathrm{PdCl}_{2}\right)_{2}\right]:$ A solution of ligand $1(0.43 \mathrm{~g}, 1.10 \mathrm{mmol})$ and $\mathrm{Pd}(\mathrm{COD}) \mathrm{Cl}_{2}(0.63 \mathrm{~g}, 2.20 \mathrm{mmol})$ in $\mathrm{CH}_{2} \mathrm{Cl}_{2}(35 \mathrm{~mL})$ was stirred at room temperature for $20 \mathrm{~h}$. The product precipitated as a yellow powder, which was collected by filtration, washed with diethyl ether and dried in vacuo. Yield $0.80 \mathrm{~g}, 97 \%$. ${ }^{1} \mathrm{H}$ NMR (200 MHz, [D 6 DMSO): $\delta=2.02\left(\mathrm{~s}, 3 \mathrm{H}, \mathrm{CH}_{3}\right), 2.12\left(\mathrm{~s}, 3 \mathrm{H}, \mathrm{CH}_{3}\right)$, $7.31-7.38(\mathrm{~m}, 3.5 \mathrm{H}, \mathrm{Ar}-H), 7.48-7.51$ (m, $2.5 \mathrm{H}, \mathrm{Ar}-H), 7.80$ (br., $3.5 \mathrm{H}, \mathrm{Ar}-H), 8.21(\mathrm{~m}, 3.5 \mathrm{H}, \mathrm{CH}), 8.83(\mathrm{~d}, J=5.2 \mathrm{~Hz}, 1 \mathrm{H}, \mathrm{CH})$, 8.88 (s, $1 \mathrm{H}$, imine-CH), 9.04 ppm (br., $1 \mathrm{H}$, pyridine- $\mathrm{C} H$ ). ${ }^{13} \mathrm{C}$ $\operatorname{NMR}\left(50 \mathrm{MHz}, \mathrm{CDCl}_{3}\right): \delta=19.30,120.23,128.90-130.16(\mathrm{~m})$, $131.39,144.01,150.91,171.36 \mathrm{ppm}$; elemental analysis (\%) calcd. for $\mathrm{C}_{26} \mathrm{H}_{22} \mathrm{~N}_{4} \mathrm{Pd}_{2} \mathrm{Cl}_{4}$ (745.14): C 41.91, $\mathrm{H} \mathrm{2.97,} \mathrm{N} \mathrm{7.51;} \mathrm{found:} \mathrm{C}$ $41.25, \mathrm{H} 2.78, \mathrm{~N} 7.67$.

[ $N, N^{\prime}$-(6, $6^{\prime}$-Dimethylbiphenyl-2,2'-diyl)bis(2-pyridylmethyl)diimine$\mathrm{Pd}]^{2+}\left(\mathrm{BF}_{4}^{-}\right)_{2}\left\{[1-\mathrm{Pd}]^{2+}\left(\mathrm{BF}_{4}\right)_{2}\right\}$ : A filtered solution of ligand 1 $(0.29 \mathrm{~g}, 0.74 \mathrm{mmol})$ in acetonitrile $(15 \mathrm{~mL})$ was added to a solution of $\left[\mathrm{Pd}\left(\mathrm{NCCH}_{3}\right)_{4}\right]^{2+}\left(\mathrm{BF}_{4}^{-}\right)_{2}(0.33 \mathrm{~g}, 0.74 \mathrm{mmol})$ in acetonitrile $(15 \mathrm{~mL})$ and the reaction mixture stirred at room temperature for $5 \mathrm{~h}$. Reaction was then evaporated and dried in vacuo. Yield $0.49 \mathrm{~g}$, $98 \% .{ }^{1} \mathrm{H}$ NMR $\left(200 \mathrm{MHz}, \mathrm{CD}_{3} \mathrm{CN}\right): \delta=1.67-1.81\left(\mathrm{~m}, 6 \mathrm{H}, \mathrm{CH}_{3}\right)$, $7.16-7.45(\mathrm{~m}, 7 \mathrm{H}, \mathrm{Ar}-H), 7.65-7.82(\mathrm{~m}, 2 \mathrm{H}, \mathrm{Ar}-H), 7.93-7.97$ (m, $2 \mathrm{H}, \mathrm{Ar}-H), 8.09-8.16(\mathrm{~m}, 3 \mathrm{H}, \mathrm{Ar}-H), 8.37-8.39 \mathrm{ppm}(\mathrm{m}, 2$ $\mathrm{H}$, imine-CH); elemental analysis (\%) calcd. for $\mathrm{C}_{26} \mathrm{H}_{22} \mathrm{~B}_{2} \mathrm{~F}_{8} \mathrm{~N}_{4} \mathrm{Pd} \cdot \mathrm{CH}_{3} \mathrm{CN}$ (711.57): C 47.26, H 3.54, N 9.84; found: C 47.44, H 3.31, N 9.92.

[N, $N^{\prime}-\left(6,6^{\prime}\right.$-Dimethylbiphenyl-2,2'-diyl)bis[(5-methyl-2-furyl)methyl]diimine-Pd( $\left.\left(\mathrm{NCCH}_{3}\right)_{2}\right]^{2+}\left(\mathrm{BF}_{4}{ }^{-}\right)_{2}\left\{\left[\left(3-\mathrm{Pd}\left(\mathrm{NCCH}_{3}\right)_{2}\right]^{2+}\left(\mathrm{BF}_{4}\right)_{2}\right\}\right.$ : This complex was prepared in the same manner as described above for complex $\left[(1-\mathrm{Pd}]^{2+}\left(\mathrm{BF}_{4}^{-}\right)_{2}\right.$. Yield $0.53 \mathrm{~g}, 94 \% .{ }^{1} \mathrm{H}$ NMR $(200 \mathrm{MHz}$, $\left.\mathrm{CD}_{3} \mathrm{CN}\right): \delta=2.08\left(\mathrm{~s}, 6 \mathrm{H}, \mathrm{NCCH}_{3}\right), 2.20\left(\mathrm{~s}, 6 \mathrm{H}\right.$, biaryl- $\left.\mathrm{CH}_{3}\right), 2.63$ $\left(\mathrm{s}, 6 \mathrm{H}\right.$, furyl- $\left.\mathrm{CH}_{3}\right), 6.52-6.55(\mathrm{~m}, 2 \mathrm{H}$, furyl-CH$), 7.30-7.39$ and $7.48-7.50 \mathrm{ppm}(\mathrm{m}, 10 \mathrm{H}, \mathrm{Ar}-\mathrm{H})$; elemental analysis (\%) calcd. for $\mathrm{C}_{28} \mathrm{H}_{30} \mathrm{~B}_{2} \mathrm{~F}_{8} \mathrm{~N}_{4} \mathrm{O}_{2} \mathrm{Pd}$ (734.60): C 45.78, $\mathrm{H} 4.11$, N 7.62; found: $\mathrm{C}$ $45.62, \mathrm{H} 3.97$, N 7.66.

[ $N, N^{\prime}$-(6, $6^{\prime}$-Dimethylbiphenyl-2,2'-diyl)bis(2-pyridylmethyl)diimine$\left.\left\{\mathrm{Pd}\left(\mathrm{NCCH}_{3}\right)_{2}\right\}_{2}\right]^{4+}\left(\mathrm{BF}_{4}^{-}\right)_{4} \quad\left\{\left[1-\left\{\mathrm{Pd}\left(\mathrm{NCCH}_{3}\right)_{2}\right\}_{2}\right]^{4+}\left(\mathrm{BF}_{4}^{-}\right)_{4}\right\}$ : This complex was prepared in the same manner as described for complex $[1-\mathrm{Pd}]^{2+}\left(\mathrm{BF}_{4}^{-}\right)_{2}$ above except for the use of only $0.15 \mathrm{~g}$ $(0.37 \mathrm{mmol})$ of ligand 1 for reaction with $0.33 \mathrm{~g}(0.74 \mathrm{mmol})$ of $\left[\mathrm{Pd}\left(\mathrm{NCCH}_{3}\right)_{4}\right]^{2+}\left(\mathrm{BF}_{4}^{-}\right)_{2}$. Yield $0.41 \mathrm{~g}, 95 \% .{ }^{1} \mathrm{H} \mathrm{NMR}(200 \mathrm{MHz}$, $\mathrm{CD}_{3} \mathrm{CN}$ ): $\delta=1.72\left(\mathrm{~s}, 6 \mathrm{H}\right.$, biaryl- $\left.\mathrm{CH}_{3}\right), 2.05$ (br., $12 \mathrm{H}, \mathrm{NCCH}_{3}$ ), $7.35-7.37(\mathrm{~m}, 8 \mathrm{H}, \mathrm{Ar}-\mathrm{H}), 7.77$ (t, $2 \mathrm{H}, \mathrm{Ar}-H), 7.97$ (d, $2 \mathrm{H}, \mathrm{Ar}-$ $H), 8.21$ (t, $2 \mathrm{H}, \mathrm{Ar}-H), 8.58 \mathrm{ppm}(\mathrm{d}, 2 \mathrm{H}, \mathrm{Ar}-H)$; elemental analysis (\%) calcd. for $\mathrm{C}_{34} \mathrm{H}_{34} \mathrm{~B}_{4} \mathrm{~F}_{16} \mathrm{~N}_{8} \mathrm{Pd}_{2}$, (1114.75): C 36.63, H 3.07, N 10.05; found: C $36.00, \mathrm{H} 3.16, \mathrm{~N} 10.74 \%$.

Crystal Structure Determinations: Single crystals of complexes 1$\mathrm{PdCl}_{2}, 1-\left(\mathrm{PdCl}_{2}\right)_{2},\left[(1-\mathrm{Pd}]^{2+}\left(\mathrm{BF}_{4}^{-}\right)_{2}\right.$ and $\left[\left(3-\mathrm{Pd}\left(\mathrm{NCCH}_{3}\right)_{2}\right]^{2+}\left(\mathrm{BF}_{4}^{-}\right)_{2}\right.$ were obtained as yellow-orange blocks upon layering a filtered re- 
Table 6. Details for the crystal structure determinations

\begin{tabular}{|c|c|c|c|c|c|c|}
\hline & $\begin{array}{l}\text { 1- } \mathrm{PdCl}_{2} \\
2 \mathrm{CH}_{2} \mathrm{Cl}_{2}\end{array}$ & $3-\mathrm{PdCl}_{2}$ & $\begin{array}{l}3-\mathrm{PdCl}_{2} \text {. } \\
\mathrm{CH}_{2} \mathrm{Cl}_{2}\end{array}$ & $\begin{array}{l}1-\left(\mathrm{PdCl}_{2}\right)_{2} \\
2 \mathrm{CH}_{2} \mathrm{Cl}_{2}\end{array}$ & $\begin{array}{l}{[1-\mathrm{Pd}]^{2+}\left(\mathrm{BF}_{4}^{-}\right)_{2} .} \\
\left(\mathrm{H}_{2} \mathrm{O}\right)_{0.5}\end{array}$ & $\begin{array}{l}{\left[3-\mathrm{Pd}\left(\mathrm{NCCH}_{3}\right)_{2}\right]^{2+}} \\
\left(\mathrm{BF}_{4}^{-}\right)_{2}\end{array}$ \\
\hline CCDC number & 243264 & 243267 & 243268 & 243265 & 243266 & 243269 \\
\hline Formula & $\begin{array}{l}\mathrm{C}_{26} \mathrm{H}_{22} \mathrm{Cl}_{2} \mathrm{~N}_{4} \mathrm{Pd} . \\
\left(\mathrm{CH}_{2} \mathrm{Cl}_{2}\right)_{2}\end{array}$ & $\mathrm{C}_{26} \mathrm{H}_{25} \mathrm{Cl}_{2} \mathrm{~N}_{2} \mathrm{O}_{2} \mathrm{Pd}$ & $\begin{array}{l}\mathrm{C}_{26} \mathrm{H}_{24} \mathrm{Cl}_{2} \mathrm{~N}_{2} \mathrm{O}_{2} \mathrm{Pd} . \\
\left(\mathrm{CH}_{2} \mathrm{Cl}_{2}\right)\end{array}$ & $\begin{array}{l}\mathrm{C}_{25} \mathrm{H}_{20} \mathrm{Cl}_{4} \mathrm{~N}_{4} \mathrm{Pd}_{2} . \\
\left(\mathrm{CH}_{2} \mathrm{Cl}_{2}\right)_{2}\end{array}$ & $\begin{array}{l}\mathrm{C}_{26} \mathrm{H}_{24} \mathrm{~N}_{4} \mathrm{Pd}\left(\mathrm{BF}_{4}\right)_{2} \\
\left(\mathrm{H}_{2} \mathrm{O}\right)_{0.5}\end{array}$ & $\begin{array}{l}\mathrm{C}_{30} \mathrm{H}_{30} \mathrm{~N}_{4} \mathrm{O}_{2} \mathrm{Pd}\left(\mathrm{BF}_{4}\right)_{2} . \\
\left(\mathrm{C}_{2} \mathrm{H}_{3} \mathrm{~N}\right)\end{array}$ \\
\hline Formula mass & 737.63 & 574.78 & 658.70 & 999.85 & 680.51 & 799.65 \\
\hline Temperature & $173(2) \mathrm{K}$ & $173(2) \mathrm{K}$ & $173(2) \mathrm{K}$ & $173(2) \mathrm{K}$ & $173(2) \mathrm{K}$ & $173(2) \mathrm{K}$ \\
\hline Crystal system & monoclinic & monoclinic & monoclinic & triclinic & monoclinic & triclinic \\
\hline Space group & $P 21 / c$ & $P 21 / C$ & $P 21 / C$ & $P \overline{1}$ & $P 21 / C$ & $P \overline{1}$ \\
\hline$a(\AA)$ & $14.003(2)$ & $8.4180(8)$ & $10.7960(7)$ & $9.0280(12)$ & $12.593(4)$ & $12.023(2)$ \\
\hline$b(\AA)$ & $14.360(1)$ & $15.2480(17)$ & $17.573(2)$ & $14.6330(17)$ & $14.363(5)$ & $12.9240(7)$ \\
\hline$c(\AA)$ & $17.917(2)$ & $18.679(3)$ & $17.484(2)$ & $15.5050(19)$ & $19.361(4)$ & $14.341(3)$ \\
\hline$\alpha\left(^{\circ}\right)$ & 90 & 90 & 90 & $113.074(11)$ & 90 & $104.178(8)$ \\
\hline$\beta\left({ }^{\circ}\right)$ & $121.844(14)$ & $99.244(8)$ & $122.895(5)$ & $98.359(13)$ & $128.47(3)$ & $99.756(11)$ \\
\hline$\gamma\left({ }^{\circ}\right)$ & 90 & 90 & 90 & $90.177(9)$ & 90 & $117.483(6)$ \\
\hline$V\left(\AA^{3}\right) ; Z$ & $3060.5(6) ; 4$ & $2366.5(5) ; 2$ & $2785.2(5) ; 4$ & $1860.4(4) ; 2$ & $2741.6(14) ; 4$ & $1810.4(5) ; 2$ \\
\hline$d_{\text {calcd. }}\left[\mathrm{g} / \mathrm{cm}^{3}\right]$ & 1.601 & 1.613 & 1.571 & 1.785 & 1.649 & 1.467 \\
\hline$\mu\left[\mathrm{mm}^{-1}\right], F(000)$ & $1.156 ; 1480$ & $1.037 ; 1164$ & $1.078 ; 1328$ & $1.713 ; 984$ & $0.758 ; 1360$ & $0.590 ; 808$ \\
\hline Crystal size (mm) & $0.25 \times 0.15 \times 0.12$ & $0.30 \times 0.25 \times 0.20$ & $0.25 \times 0.18 \times 0.12$ & $0.20 \times 0.05 \times 0.05$ & $0.18 \times 0.04 \times 0.02$ & $0.20 \times 0.20 \times 0.20$ \\
\hline Theta range $\left(^{\circ}\right)$ & 5.03 to 27.51 & 5.03 to 27.51 & 5.01 to 27.53 & 2.66 to 27.57 & 3.04 to 25.25 & 3.10 to 27.50 \\
\hline Reflections col- & $24160 / 6960$ & $16675 / 5352$ & $29085 / 6210$ & $28531 / 8435$ & $39662 / 4875$ & $26221 / 8243$ \\
\hline lected/unique & {$[R($ int $)=0.0714]$} & {$[R($ int $)=0.1057]$} & {$[R($ int $)=0.0456]$} & {$[R($ int $)=0.0572]$} & {$[R($ int $)=0.1233]$} & {$[R($ int $)=0.0459]$} \\
\hline$T_{\max }, T_{\min }$ & $0.8737,0.7609$ & $0.8194,0.7461$ & $0.8816,0.7744$ & $0.9193,0.7258$ & $0.9850,0.8757$ & $0.9127,0.8932$ \\
\hline $\begin{array}{l}\text { Data/restraints/ } \\
\text { parameters }\end{array}$ & $6960 / 0 / 352$ & $5352 / 0 / 302$ & $6210 / 0 / 325$ & $8435 / 80 / 462$ & $4875 / 74 / 416$ & $8243 / 0 / 463$ \\
\hline $\mathrm{GoF}\left(F^{2}\right)$ & 0.989 & 0.963 & 0.628 & 1.050 & 1.033 & 1.030 \\
\hline $\begin{array}{l}\text { Final } R \text { indices } \\
{[I>2 \sigma(I)]}\end{array}$ & $\begin{array}{l}R 1=0.0471 \\
w R 2=0.0883\end{array}$ & $\begin{array}{l}R 1=0.0649, \\
w R 2=0.1009\end{array}$ & $\begin{array}{l}R 1=0.0344, \\
w R 2=0.1232\end{array}$ & $\begin{array}{l}R 1=0.0597 \\
w R 2=0.1530\end{array}$ & $\begin{array}{l}R 1=0.0726 \\
w R 2=0.1781\end{array}$ & $\begin{array}{l}R 1=0.0381 \\
w R 2=0.0823\end{array}$ \\
\hline $\begin{array}{l}R \text { indices } \\
\text { (all data) }\end{array}$ & $\begin{array}{l}R 1=0.0993, \\
\omega R 2=0.1025\end{array}$ & $\begin{array}{l}R 1=0.1561 \\
w R 2=0.1236\end{array}$ & $\begin{array}{l}R 1=0.0537, \\
w R 2=0.1545\end{array}$ & $\begin{array}{l}R 1=0.0863 \\
w R 2=0.1698\end{array}$ & $\begin{array}{l}R 1=0.1163 \\
w R 2=0.1990\end{array}$ & $\begin{array}{l}R 1=0.0584 \\
\omega R 2=0.0887\end{array}$ \\
\hline Largest diff. peak & $0.671 \mathrm{eA}^{-3}$ & $0.539 \mathrm{eA}^{-3}$ & $0.997 \mathrm{eA}^{-3}$ & $1.136 \mathrm{eA}^{-3}$ & $1.047 \mathrm{eA}^{-3}$ & $0.572 \mathrm{eA}^{-3}$ \\
\hline
\end{tabular}

action solution with diethyl ether at ambient temperature. Crystals of 3-PdCl 2 were obtained at $4{ }^{\circ} \mathrm{C}$; at room temperature, 3- $\mathrm{PdCl}_{2}$ gave crystals with a different unit cell. Crystals selected for X-ray measurements were mounted on a glass fiber using the oil-drop method. Data were collected on a Nonius-Kappa CCD diffractometer using Mo-Ka radiation $(71.073 \mathrm{pm})$ and a graphite monochromator. Structures were solved by direct methods. All non-hydrogen atoms were refined anisotropically. ${ }^{[33]}$ Hydrogen atoms were introduced at calculated positions and refined with fixed geometry with respect to their carrier atoms. Cell parameters and data collection parameters are summarized in Table 6. CCDC243264 (for 1-PdCl 2 ), CCDC-243267 and CCDC-243268 (for 3$\mathrm{PdCl}_{2}$, two crystals with different structures), CCDC-243265 (for 1- $\left.\left(\mathrm{PdCl}_{2}\right)_{2}\right), \mathrm{CCDC}-243266$ (for $\left.[1-\mathrm{Pd}]^{2+}\left(\mathrm{BF}_{4}{ }^{-}\right)_{2}\right)$ and CCDC243269 (for $\left.\left[3-\mathrm{Pd}\left(\mathrm{NCCH}_{3}\right)_{2}\right]^{2+}\left(\mathrm{BF}_{4}^{-}\right)_{2}\right)$ contain the supplementary crystallographic data for this paper. These data can be obtained free of charge from The Cambridge Crystallographic Data Centre via www.ccdc.cam.ac.uk/data_request/cif.

Norbornene Polymerizations: The dichloro complexes 1- $\mathrm{PdCl}_{2}, 2$ $\mathrm{PdCl}_{2}$ and 3- $\mathrm{PdCl}_{2}(20 \mu \mathrm{mol})$ were suspended in toluene $(60 \mathrm{~mL})$, MAO (4 mL, $20 \mathrm{mmol})$ and 2-norbonene $(2.1 \mathrm{~g}, 22.3 \mathrm{mmol})$ were added and the reaction solution stirred at room temperature for $1 \mathrm{~h}$. Conversions measured from the isolated products were 64,71 and $38 \%$, respectively. In the case of complexes $\left[1-\mathrm{Pd}^{2+}\left(\mathrm{BF}_{4}{ }^{-}\right)_{2}\right.$, and $\left[3-\mathrm{Pd}\left(\mathrm{NCCH}_{3}\right)_{2}\right]^{2+}\left(\mathrm{BF}_{4}^{-}\right)_{2}$ norbornene was added to a solution of the complex $(50 \mathrm{mg}, 66 \mu \mathrm{mol})$ in $\mathrm{CH}_{2} \mathrm{Cl}_{2}(50 \mathrm{~mL})$, chlorobenzene $(5 \mathrm{~mL})$ and nitrobenzene $(1 \mathrm{~mL})$ and stirred at room tempera- ture for $1 \mathrm{~h}$. Conversions were 0 and $44 \%$, respectively. After quenching the reaction by addition of methanol $(200 \mathrm{~mL})$, acidified with $\mathrm{HCl}(1 \mathrm{~mL})$, the precipitate was collected by filtration, washed with methanol and dried at $60^{\circ} \mathrm{C}$. Decomposition points were determined with thermogravimetric balance under $\mathrm{N}_{2}$ flow. ${ }^{1} \mathrm{H}$ NMR $\left(200 \mathrm{MHz}, \mathrm{CDCl}_{3}\right): \delta=0.87-2.23$ (br. m, $10 \mathrm{H}$ ) ppm. ${ }^{13} \mathrm{C} \mathrm{NMR}$ (50 MHz, $\mathrm{CDCl}_{3}$ ): $\delta=28-44$ (br. m), $48-55$ ppm (br. m).

\section{Acknowledgments}

M.K. thanks the foundation of Alfred Kordelin for support. The Academy of Finland is acknowledged for financial support via Centre of Excellence (Bio- and Nanopolymer Research Group, project 77317).

[1] a) E. L. Mutterties, M. J. Krause, Angew. Chem. Int. Ed. Engl. $1983,22,135-148$; b) D. A. Roberts, G. L. Geoffroy in Comprehensive Organometallic Chemistry, vol. 6 (Eds.: E. Wilkinson, F. G. A. Stone, E. W. Abel), Pergamon, Oxford, 1982, chapter 40 , pp. $763-877$; c) W. Beck, B. Niemer, M. Wieser, Angew. Chem. 1993, 105(7), 969-996; Angew. Chem. Int. Ed. Engl. 1993, 32, 923-949; d) E. K. van den Beuken, B. L. Feringa, Tetrahedron 1998, 54, 12985-13011; e) S. Barlow, D. O'Hare, Chem. Rev. 1997, 97, 637-670.

[2] N. Guo, L. Li, T. J. Marks, J. Am. Chem. Soc. 2004, 126, $6542-6543$. 
[3] a) M. E. Broussard, B. Juma, S. G. Train, W.-J. Peng, S. A. Laneman, G. G. Stanley, Science 1993, 260, 1784-1788; b) R. C. Matthews, D. K. Howell, W.-J. Peng, S. G. Train, W. D. Treleaven, G. G. Stanley, Angew. Chem. 1996, 108, 2402-2405; Angew. Chem. Int. Ed. Engt. 1996, 35, 2253-2256; c) W. J. Peng, S. G. Train, D. K. Howell, F. R. Fronczek, G. G. Stanley, Chem. Commun. 1996, 2607-2612; d) G. Süss-Fink, Angew. Chem. 1994, 106, 71-73; Angew. Chem. Int. Ed. Engl. 1994, 33, 67-69.

[4] C. J. McKenzie, R. Robson, J. Chem. Soc., Chem. Commun. 1988, 112-114.

[5] B.-H. Xia, H.-X. Zhang, C.-M. Che, K.-H. Leung, D. L. Phillips, N. Zhu, Z.-Y. Zhou, J. Am. Chem. Soc. 2003, 125, $10362-10374$

[6] A. Togni, L. M. Venanzi, Angew. Chem.1994, 106, 517-547; Angew. Chem. Int. Ed. Engl. 1994, 33, 497-526.

[7] G. S. Smith, S. F. Mapolie, J. Mol. Cat. A: Chem. 2004, 213,187-192.

[8] R. Chen, S. F. Mapolie, J. Mol. Cat. A. Chem. 2003, 193, 3340.

[9] C. R. Baar, M. C. Jennings, R. J. Puddephatt, Organometallics 2001, 20, 3459-3465.

[10] a) O. Hoarau, H. Ait-Haddou, J.-C. Daran, D. Cramailere, G. G. A. Balavoine, Organometallics 1999, 18, 4718-4723; b) H. Ait-Haddou, O. Hoarau, D. Cramailere, F. Pezet, J.-C. Daran, G. G. A. Balavoine, Chem. Eur. J. 2004,10, 699-707; c) For a recent review about Pd-catalyzed enantioselective transformations, see L. F. Tietze, H. Ila, H. P. Bell, Chem. Rev. 2004, $104,3453-3516$.

[11] a) H. Suga, A. Kakehi, S. Ito, T. Ibata, T. Fudo, Y. Watanabe, Y. Kinoshita, Bull. Chem. Soc. Jpn. 2003, 76, 189-199; b) K. M. Gillespie, C. J. Sanders, P. O'Shaughnessy, I. Westmoreland, C.P. Thickitt, P. Scott, J. Org. Chem. 2002, 67, $3450-3458$.

[12] a) H.Takaya, T. Ohta, R. Noyori in Catalytic Asymmetric Synthesis (Ed.: I. Ojima), VCH, Weinheim, Germany, 1993; b) H. B. Kagan, O. Riant, Chem. Rev. 1992, 92, 1007-1019; c) H. Suga, T. Fudo, T. Ibata, Synlett 1998, 8, 933-935; c) N. Yoshikawa, Y. M. A. Yamada, J. Das, H. Sasai, M. Shibasaki, J. Am. Chem. Soc. 1999, 121, 4168-4178; d) H. Ishitani, M. Ueno, S. Kobayashi, J. Am. Chem. Soc. 2000, 122, 8180-8186; e) A. H. Hoveyda, R. R. Schrock, Chem. Eur. J. 2001, 7, $945-950$; f) D. R. Cefalo, A. F. Kiely, M. Wuchrer, M. Jamieson, R. R. Schrock, A. H. Hoveyda, J. Am. Chem. Soc. 2001, 123, 3139-3140.

[13] a) F. Lions, K. V. Martin, J. Am. Chem. Soc. 1957, 79, $1273-1275$; b) S. Knapp, T. P. Keenan, X. Zhang, R. Fikar, J. A. Potenza, H. Schugar, J. Am. Chem. Soc. 1987, 109, $1882-1883$; c) E. Müller, C. Piquet, G. Bernadinella, A. F. Williams, Inorg. Chem. 1988, 27, 849-855; d) H. Frydendahl, H. Toftlund, J. Becher, J. C. Dutton, K. S. Murray, L. F. Taylor, O. P. Anderson, E. R. T. Tiekink, Inorg. Chem. 1995, 34, 4467-4476; e) R. Noyori, H. Takaya, Acc. Chem. Res. 1990, $23,345-350$; f) M. Kitamura, T. Ohkuma, S. Inoue, N. Sayo, H. Kumobayashi, S. Akutagawa, T. Ohta, H. Takaya, R. Noyori, J. Am. Chem. Soc. 1988, 110,629-631; g) J. M. Brown, S. Woodward, J. Org. Chem. 1991, 56, 6803-6809; h) N. W. Alcock, J. M. Brown, D. I. Hulmes, Tetrahedron: Asym. 1993, 4, 743-756.

[14] M. Réglier, C. Jorand, B. Waegell, J. Chem. Soc., Chem. Commun. 1990, 24, 1752-1755.

[15] a) M. Gomez, G. Muller, D. Panyella, M. Rocamora, E. Dunach, S. Olivero, J.-C. Clinet, Organometallics 1997, 16, 5900-5908; b) A. S. Abu-Surrah, U. Thewalt, B. Rieger, J. Organomet. Chem. 1999, 587,58-66; c) R. Feldhaus, J. Koeppe, R. Mattes, U. Voet, Z. Naturforsch. Teil B: Chem. Sci. 1996, 51, 1449-1458; d) F. Gomez-de la Torre, A. de la Hoz, F. A. Jalon, B. R. Manzano, A. M. Rodriguez, J. Elguero, M. Martinez-Ripoll, Inorg. Chem. 2000, 39, 1152-1162.
[16] a) X.-G. Zhou, J.-S. Huang, X.-Q. Yu, Z.-Y. Zhou, C.-M. Che, J. Chem. Soc., Dalton Trans. 2000, 1075-1080; b) R. Kivekas, A. Pajunen, A. Navarrete, E. Colacio, Inorg. Chim. Acta 1999, 284, 292-295; c) M. R. A. Pillai, C. L. Barnes, C. S. John, D. E. Troutner, E. O. Schlemper, J. Crystallogr. Spectr. Res.1993, 23, 949-953; d) N. Ahmad, Inorg. Chim. Acta 1989, $155,237-241$.

[17] a) M. Gomez, S. Jansat, G. Muller, D. Panyella, P. W. N. M. van Leeuwen, P. C. J. Kamer, K. Goubitz, J. Fraanje, Organometallics 1999, 18, 4970-4981; b) U. Burckhardt, M. Baumann, G. Trabesinger, V. Gramlich, A. Togni, Organometallics $1997,16,5252-5259$; c) A. G. J. Ligtenbarg, E. K. van den Beuken, A. Meetsma, N. Veldman, W. J. J. Smeets, A. L. Spek, B. L. Feringa, J. Chem. Soc., Dalton Trans. 1998, 263-270; d) E. K. van den Beuken, A. Meetsma, H. Kooijman, A. L. Spek, B. L. Feringa, Inorg. Chim. Acta 1997, 264, 171-183; e) T. G. Schenck, J. M. Downes, C. R. C. Milne, P. B. Mackenzie, T. G. Boucher, J. Whelan, B. Bosnich, Inorg. Chem. 1985, 24, 2334-2337.

[18] L. K. Johnson, C. M. Killian, M. Brookhart, J. Am. Chem. Soc. 1995, 117, 6414-6415.

[19] Labile coordination of diimine ligands with oxygen- or sulfurcontaining side arms has been reported: a) X.-G. Fang, B. L. Scott, J. G. Watkin, G. J. Kubas, Organometallics 2000, 19, 4193-4195; b) X. Fang, J. G. Watkin, B. L. Scott, G. J. Kubas, Organometallics 2001, 20, 3351-3354.

[20] a) M. Kettunen, C. Vedder, F. Schaper, M. Leskelä, I. Mutikainen, H.-H. Brintzinger, Organometallics 2004, 23, $3800-3807$; b) C. Vedder, Doctoral dissertation, University of Konstanz, Germany, 2002.

[21] The ratio of the integrals of the methyl proton signals changed gradually when the NMR sample was heated. DMSO as a solvent did not allow low-temperature NMR studies.

[22] When grown from $\mathrm{CH}_{2} \mathrm{Cl}_{2} / \mathrm{Et}_{2} \mathrm{O}$ solution at room temperature, $3-\mathrm{PdCl}_{2}$ crystallized in another modification without a solvent molecule in the unit cell. The coordination geometry of this modification is practically superimposable to that of $3-\mathrm{PdCl}_{2}$ described above, but it contains one of the uncoordinated furyl side arms in a different orientation.

[23] When ligand 1 was reacted with one equivalent of $\mathrm{Pd}(\mathrm{COD})$ $\mathrm{Cl}_{2}$ at room temperature, complex 1-[ $\left.\mathrm{PdCl}_{2}\right]_{2}$ didprecipitate first under partial consumption of the ligand, while mononuclear 1- $\mathrm{PdCl}_{2}$ was isolated later by recrystallization.

[24] a) S. Cosar, M. B. L. Janik, M. Flock, E. Freisinger, E. Farkas, B. Lippert, J. Chem. Soc., Dalton Trans. 1999, 2329-2336; b) W. Wong-Ng, P. T. Cheng, V. Kocman, H. Luth, S. C. Nyburg, Inorg. Chem. 1979, 18,2620-2623; c) B. Oskui, W. S. Sheldrick, Eur. J. Inorg. Chem. 1999, 1325-1333.

[25] C.-M. Che, J.-S. Huang, Coord. Chem. Rev. 2003, 242, 97-113 and references cited therein.

[26] Dihedral angles of ca. $10.5^{\circ}$ between two adjacent N-Pd$\mathrm{O}$ (phenoxide)planes have been reported for binaphtyl salen $\mathrm{Pd}$ complexes (see ref. ${ }^{[16 a]}$ ).

[27] To the best of our knowledge, no structurally characterized $\mathrm{Pd}^{\mathrm{II}}$ complexes with oxygen-coordinated furyl ligands have been reported so far.

[28] Pentacoordinate $\mathrm{Pd}^{\text {II }}$ centers have been reported to occur in complexes with constrained ligand frameworks: a) T. J. Hubin, N. W. Alcock, D. H. Busch, Acta Crystallogr. Sect. C 199955 , 1404; b) R. Garrone, A. M. Romano, R. Santi, R. Millini, Organometallics 1998, 17, 4519-4522.

[29] Other studies on norbornene polymerisation with neutral or cationic Pd complexes: a) C. Mehler, W. Risse, Makromol. Chem. Rapid Commun. 1991, 12, 255-259; b) C. Mehler, W. Risse, Macromolecules 1992, 25, 4226-4228; c) A. Sen, T. W. Lai, Organometallics 1982, 1, 415-417; d) A. S. Abu-Surrah, B. Rieger, J. Mol. Catal. 1998, 128, 239-243.

[30] Use of an enantiomerically pure $\mathrm{Pd}^{\mathrm{II}}$ complex with a $(1 R, 2 R)$ (-)- $N, N^{\prime}$-bis(quinoline-2-methylene)diiminocyclohexane backbone for MAO-activated norbornene polymerization has been 
reported to give, under similar conditions, polynorbornene with an elevated decomposition temperature of $415^{\circ} \mathrm{C}$ (see ref..$^{[15 b]}$ ).

[31] S. Kanoh, S. Goka, N. Murose, H. Kubo, M. Kondo, T. Sugino, M. Motoi, H. Suda, Polym. J. 1987, 19, 1047-1065.

[32] D. Drew, J. R. Doyle, Inorg. Synth. 1972, 13, 47-55.
[33] G. M. Sheldrick, SHELXTL, 1990, and SHELXTL, 1997, University of Göttingen, Germany. G. M. Sheldrick, $S A D A B S$, 1996, University of Göttingen, Germany. G. M. Sheldrick, SHELX97, 1997, University of Göttingen, Germany. 